\section{Vietnam Journal of Agricultural Sciences}

\title{
Comprehensive Analysis of Morphological Variation among 24 Tomato (Solanum Lycopersicum) Genotypes Oriented to Ornamental Breeding in Vietnam
}

\section{Tran Thien Long ${ }^{1,2}$, Nguyen Hong Minh ${ }^{1,2}$, Nguyen Tuan Anh ${ }^{1,2}$, Tran Thi Minh Hang ${ }^{3}$, Nguyen Thi Hoa ${ }^{4}$, Nguyen Tien Long ${ }^{1} \&$ Nguyen Thi Minh ${ }^{1}$}

\author{
${ }^{1}$ High Quality Vegetable Research and Development Center, Vietnam National University \\ of Agriculture, Hanoi 131000, Vietnam \\ ${ }^{2}$ Department of Plant genetics and breeding, Faculty of Agronomy, Vietnam National \\ University of Agriculture, Hanoi 131000, Vietnam \\ ${ }^{3}$ Department of Horticulture and Landscape, Faculty of Agronomy, Vietnam National \\ University of Agriculture, Hanoi 131000, Vietnam \\ ${ }^{4}$ Department of Plant Genetics and Breeding, Faculty of Agronomy, Vietnam National \\ University of Agriculture, Hanoi 131000, Vietnam
}

\begin{abstract}
Tomato is one of the most important vegetables cultivated in Vietnam. Besides its regular consumption as a vegetable, a new demand for using tomato as a decorative plant on special occasions was identified in recent years. This study aimed to characterize new tomato accessions on their desirable morphological traits to select potential materials for further breeding programs of ornamental tomato varieties in Vietnam. Twenty-four heirloom tomato genotypes were evaluated on 19 morphological traits. Based on the describing system for tomato developed by the International Plant Genetic Resources Institute (IPGRI, 1996), significant variation was assessed in both qualitative and quantitative traits related to fruit morphology. The results of principle component analysis indicated that three main principle components explained over $60 \%$ of the total phenotypic variation. The five traits of fruit size, fruit shoulder shape, fruit cross-sectional shape, number of locules, and shape of the pistil scar were recommended as important traits for clustering tomato genotypes in this study. In addition, the 24 genotypes were classified at the coefficient of 0.39 into six different clusters. Finally, six interesting accessions, AU66, AU67, AU68, AU73, AU79, and AU83 (with strange fruit colors and shapes), were selected as potential materials for further breeding programs of ornamental tomato in Vietnam.
\end{abstract}

\section{Keywords}

Ornamental tomato breeding, cluster analysis, principle component analysis 


\section{Introduction}

Tomato (Solanum lycopersicum) originated in the Andean region of South America, was domesticated in Mexico, spread to Europe in the early $16^{\text {th }}$ century, and later to the whole world (Blanca et al., 2012). In 2017, tomato was the most consumed vegetable worldwide with over 177 million tons produced for both fresh and processing markets (Omondi, 2017). In Vietnam, tomato has been cultivated for over 100 years and has become one of the highest valued economic vegetables for both the domestic market and exporting (Ha, 2015).

Among many different breeding programs, diversifying the germplasm is always defined as one of the most important steps. The genetic diversity data of many tomato germplasms have been reported and used for different breeding purposes such as developing elite inbred lines (Wang et al., 2016; Kaur et al., 2019), predicting potential heterosis between two parents in hybrid tomato breeding (Jin et al., 2019), and identifying valuable materials for specific breeding targets. Some breeding targets of greatest concern include: increasing fruit yield components (Reddy et al., 2013; Ziaf et al., 2016), improving fruit quality (Panthee et al., 2013; Singh et al., 2018), and accelerating adaptability to both biotic and abiotic stresses (Panthee \& Chen, 2010; Danso et al., 2011; Hoagland et al., 2015; Hanson et al., 2016).

In Vietnam, besides the above traditional breeding targets, a new breeding consideration for decorative plants has recently been identified based on the trend of using agricultural crops for ornamental purposes. Tomato has the potential to lead the trend because of its diversity in different traits, especially in the fruit shape, fruit color, dwarf stem, simple or condensed leaf styles, and long shelf-life (Martí et al., 2006; Saito et al., 2011; Bhattarai et al., 2018). According to Vegetable Gardening the Colonial Williamsburg Way (Greene, 2012), many vegetables, including tomato, have the potential for use as ornamental plants in the garden due to their unique morphological aspects. Tomato is currently planted for both decorative and vegetable purposes in botanic gardens in European countries (Greene, 2012). This study aims to characterize the morphological diversity among new tomato genotypes originating from different countries to identify desirable traits (mainly related to fruit) for ornamental tomato breeding programs. The results indicated significant morphological variation among the 24 tomato genotypes studied in terms of fruit-related traits. Some accessions with interesting fruit shape and color were selected for further breeding programs of ornamental tomato in Vietnam.

\section{Materials and Methods}

\section{Plant materials}

Twenty-four heirloom tomato genotypes originating from America (15), Europe (8), and Asia (1) were used in this study (Table 1). The seeds were sown on nursery beds inside a net house on 15 September 2018. After 30 days, the seedlings were transplanted to an experimental open field at a high-quality vegetable research and development center, Vietnam National University of Agriculture, Vietnam.

\section{Experimental design}

The experiment was designed following a randomized complete block design (RCBD) with two replications. Twenty-two plants of each genotype were grown in an experimental plot area of $8 \mathrm{~m}^{2}$, planting two rows per bed; the plant to plant spacing was $50 \mathrm{~cm}$, and the distance between two rows was $60 \mathrm{~cm}$. All the genotypes were grown under the same conditions and standard agronomic management practices as described by Srinivasan (2010).

\section{Data collection}

Twenty-four tomato genotypes were evaluated on 19 morphologic traits related to plant structure, fruit morphology, and quality. Each parameter was recorded as the average performance of 6 different plants per genotype per replication. For measuring the fruit morphological traits (such as fruit length, fruit width, etc.), 10 random fruits were used. The measurements of 13 qualitative traits were used for the clustering analysis. The measurements 
Table 1. The name, origin, and code of the 24 tomato genotypes in the experiment

\begin{tabular}{|c|c|c|c|c|c|c|c|}
\hline Name & Origin & Code & $\begin{array}{l}\text { Code for clustering } \\
\text { analysis }\end{array}$ & Name & Origin & Code & $\begin{array}{l}\text { Code for clustering } \\
\text { analysis }\end{array}$ \\
\hline Tigerella & UK & AU66 & OTU-1 & Reisetomate & Germany & AU79 & OTU-13 \\
\hline Greenzebra & USA & AU67 & OTU-2 & Tropic & USA & AU80 & OTU-14 \\
\hline Black Krim & Russia & AU68 & OTU-3 & Tommy Toe & USA & AU82 & OTU-15 \\
\hline $\begin{array}{c}\text { Broad Ripple Yellow } \\
\text { Currant }\end{array}$ & USA & AU70 & OTU-4 & Moneymaker & UK & AU83 & OTU-16 \\
\hline Campbell'33 & USA & AU71 & OTU-5 & Principe Borghese & Italy & AU85 & OTU-17 \\
\hline Roma & USA & AU72 & OTU-6 & $\begin{array}{l}\text { Rouge de } \\
\text { Marmande }\end{array}$ & Spain & AU86 & OTU-18 \\
\hline Beams Yellow Pear & USA & AU73 & OTU-7 & Jaune Flamme & France & AU87 & OTU-19 \\
\hline Beefsteak & USA & AU74 & OTU-8 & Mortgage Lifter & USA & AU88 & OTU-20 \\
\hline Thai Pink Egg & Thailand & AU75 & OTU-9 & Cherry Camp Joy & USA & AU89 & OTU-21 \\
\hline Red Oxheart & USA & AU76 & OTU-10 & Cherry Cocktail & UK & AU91 & OTU-22 \\
\hline Red Fig & USA & AU77 & OTU-11 & $\begin{array}{c}\text { Cherry Yellow } \\
\text { Honeybee }\end{array}$ & USA & AU92 & OTU-23 \\
\hline Jubilee & USA & AU78 & OTU-12 & Cherry Red Pear & USA & AU93 & OTU-24 \\
\hline
\end{tabular}

were carried out according to the guidance of the International Plant Genetic Resource Institute (Ipgri, 1996) with modifications in measuring leaf color and the presence of green (shoulders) tops on the fruit (Table 2).

\section{Data analyis}

Analysis of variance (ANOVA) was conducted using the Statistical Tool for Agricultural Research (STAR) software with the significance level of $\mathrm{P}<0.05$. Tukeys's honest significant difference test was used to separate mean values at $\mathrm{P}<0.05$. A cluster analysis was performed using the UPGMA clustering method with NTSYSpc, version 2.10q (Rohlf, 2000). A correlation analysis was performed using Pearson's method as described previously (Hauke \& Kossowski, 2011) and the principle components were analyzed by Analyse-it (Excel).

\section{Results}

\section{Diversity in morphological traits}

A high level of diversity was observed through both the vegetative and reproductive traits among the 24 genotypes. In the plant growth type, there were 4 determinate genotypes (accounting for 16.6\%), 10 semi-determinate $(41.7 \%)$, and 10 indeterminate genotypes (41.7\%). The majority of the genotypes (17 out of 24) had the standard leaf style while the other 7 genotypes had the peruvianum style. Additionally, the 24 genotypes were allocated into two main groups based on their leaf color and intensity with 13 light green $(54.1 \%)$ and 10 green $(41.7 \%)$, while only 1 genotype had dark green leaves $(4.2 \%)$ (Table 3).

The main characteristics considered for ornamental purposes in tomato are fruit morphology, plant structure, and leaf type. This study focused mainly on characterizing the fruitrelated traits of the experimental genotypes. Onethird of the genotypes had a simple flower cluster, while two-thirds were complex in these traits (Table 3 and Figure 1a). A higher complex flower inflorescence is likely to be preferred for decorative tomato. The phenotypes of the greenmature fruit were also diverse with 3 white shoulder genotypes (12\%) and 3 slight green shoulder genotypes $(12 \%)$, while the majority had exposed shoulders with green ( 7 genotypes) or dark green (11 genotypes) colors, which accounted for $29.2 \%$ and $45.8 \%$, respectively (Table 3 and Figure 1b).

Fruit shape and color are the most important 
Table 2. Measuring scale used for tomato phenotyping

\begin{tabular}{|c|c|c|c|c|c|}
\hline Traits & Measuring scale & IPGRI & Traits & Measuring scale & IPGRI \\
\hline $\begin{array}{l}\text { Plant growth } \\
\text { type }^{*}(\mathrm{GT})\end{array}$ & $\begin{array}{l}\text { (1) Dwarf } \\
\text { (2) Determinate } \\
\text { (3) Semi- determinate } \\
\text { (4) Indeterminate }\end{array}$ & 7.1.2.1 & 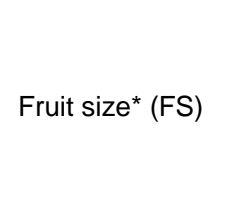 & $\begin{array}{l}\text { (1) Very small } \\
\text { (2) Small } \\
\text { (3) Intermediate } \\
\text { (4) Large } \\
\text { (5) Very large }\end{array}$ & 7.2.2.6 \\
\hline Leaf type* $(\mathrm{LT})$ & $\begin{array}{c}\text { (1) Dwarf } \\
\text { (2) Potato } \\
\text { (3) Standard } \\
\text { (4) Peruvianum } \\
\text { (5) Pimpinellifolium } \\
\text { (6) Hirsutum } \\
\text { (7) Other }\end{array}$ & 7.1.2.9 & $\begin{array}{c}\text { Exterior color of } \\
\text { the mature fruit } \\
\text { (ECOMF) }\end{array}$ & $\begin{array}{l}\text { (1) Green } \\
\text { (2) Yellow } \\
\text { (3) Orange } \\
\text { (4) Pink } \\
\text { (5) Red } \\
\text { (6) Other }\end{array}$ & 7.2.2.11 \\
\hline Leaf color & $\begin{array}{l}\text { (1) Light green } \\
\text { (2) Green } \\
\text { (3) Dark green }\end{array}$ & & $\begin{array}{l}\text { Intensity of the } \\
\text { exterior color } \\
\text { (IOEC) }\end{array}$ & $\begin{array}{l}\text { (3) Light } \\
\text { (5) Intermediate } \\
\text { (7) Dark }\end{array}$ & 7.2.2.12 \\
\hline $\begin{array}{l}\text { Inflorescence } \\
\text { type* (IT) }\end{array}$ & $\begin{array}{l}\text { (1) Generally uniparous } \\
\text { (2) Partly uniparous, partly } \\
\text { multiparous } \\
\text { (3) Generally multiparous }\end{array}$ & 7.2.1.1 & $\begin{array}{l}\text { Fruit shoulder } \\
\text { shape* (FSS) }^{*}\end{array}$ & $\begin{array}{l}\text { (1) Flat } \\
\text { (3) Slightly depressed } \\
\text { (5) Moderately depressed } \\
\text { (7) Strongly depressed }\end{array}$ & 7.2.2.16 \\
\hline $\begin{array}{l}\text { Intensity of the } \\
\text { greenback (green } \\
\text { shoulder)* } \\
\text { (IOGB) }\end{array}$ & $\begin{array}{l}\text { (0) Absent } \\
\text { (3) Slightly } \\
\text { (5) Intermediate } \\
\text { (7) Strong }\end{array}$ & $\begin{array}{l}7.2 .2 .2 \\
7.2 .2 .3\end{array}$ & $\begin{array}{l}\text { Shape of the } \\
\text { pistil scar* } \\
\text { (SOPS) }\end{array}$ & $\begin{array}{l}\text { (1) Dot } \\
\text { (2) Stellate } \\
\text { (3) Linear } \\
\text { (4) Irregular }\end{array}$ & 7.2.2.32 \\
\hline \multirow{4}{*}{$\begin{array}{l}\text { Predominant fruit } \\
\text { shape* (PFS) }^{*}\end{array}$} & $\begin{array}{l}\text { (1) Flattened } \\
\text { (2) Slightly flattened } \\
\text { (3) Rounded }\end{array}$ & & $\begin{array}{l}\text { Fruit cross- } \\
\text { sectional shape* } \\
\text { (FCSS) }\end{array}$ & $\begin{array}{l}\text { (1) Round } \\
\text { (2) Angular } \\
\text { (3) Irregular }\end{array}$ & 7.2.2.29 \\
\hline & $\begin{array}{l}\text { (4) High rounded } \\
\text { (5) Heart shaped } \\
\text { (6) Cylindrical }\end{array}$ & 7.2.2.5 & $\begin{array}{l}\text { Fruit blossom } \\
\text { end shape } \\
\text { (FBES) }\end{array}$ & $\begin{array}{l}\text { (1) Intended } \\
\text { (2) Flat } \\
\text { (3) Pointed }\end{array}$ & 7.2.2.33 \\
\hline & $\begin{array}{l}\text { (7) Pyriform } \\
\text { (8) Ellipsoid }\end{array}$ & & Fruit length & Quantitative & 7.2.2.9 \\
\hline & (9) Other & & Fruit width & Quantitative & 7.2.2.10 \\
\hline $\begin{array}{l}\text { Total soluble } \\
\text { solids* }\end{array}$ & Quantitative & 8.3 .4 & $\begin{array}{l}\text { Thickness of } \\
\text { pericarp }\end{array}$ & Quantitative & 7.2.2.25 \\
\hline $\begin{array}{c}\text { Number of seeds } \\
\text { per fruit }\end{array}$ & Quantitative & & $\begin{array}{c}\text { Number of } \\
\text { locules }^{*} \text { (NOL) }\end{array}$ & Quantitative & 7.2.2.31 \\
\hline
\end{tabular}

Note: Traits marked with * were used for the clustering analysis; the abbreviations inside the brackets are presented in the biplot chart of the pattern of PC1 and PC2 (Figure 4).

fruit traits for ornamental tomato. Among the 24 genotypes, 8 types of fruit shapes and 6 different fruit colors were recorded. In terms of fruit shape, besides the common shapes including round, high round, or flat, some genotypes had a very good looking shape such as water drop (AU73 and AU77), heart shape (AU78 and AU87), or pyriform shape (AU72). The classification of the 24 genotypes based on fruit shape can be seen in Table 3 and Figure 1c. Similarly, the fruit color of the 24 tomato genotypes was also highly diverse with some interesting colors: 14 genotypes had red fruit (58.4\%), followed by 4 in yellow (16.7\%), 2 each in orange and pink $(8.3 \%), 1$ in green $(4.2 \%)$, and 1 in black color (AU68- Black karim) (Table 3 and Figure 1d). Combining the observations on fruit shape and color, several 
Table 3. Classification of the 24 tomato genotypes based on morphological traits

\begin{tabular}{|c|c|c|c|}
\hline Traits & Class & Number of genotypes & Frequency (\%) \\
\hline \multirow{4}{*}{ Plant growth type } & 1. Dwarf & 0 & 0 \\
\hline & 2. Determinate & 4 & 16.6 \\
\hline & 3. Semi-determinate & 10 & 41.7 \\
\hline & 4. Indeterminate & 10 & 41.7 \\
\hline \multirow{7}{*}{ Leaf type } & 1. Dwarf & 0 & 0 \\
\hline & 2. Potato & 0 & 0 \\
\hline & 3. Standard & 17 & 70.8 \\
\hline & 4. Peruvianum & 7 & 29.2 \\
\hline & 5. Pimpinellifolium & 0 & 0 \\
\hline & 6. Hirsutum & 0 & 0 \\
\hline & 7. Other & 0 & 0 \\
\hline \multirow{3}{*}{ Leaf color } & 1. Light green & 13 & 54.1 \\
\hline & 2. Green & 10 & 41.7 \\
\hline & 3. Dark green & 1 & 4.2 \\
\hline \multirow{3}{*}{ Inflorescence type } & 1. Generally uniparous & 8 & 33.3 \\
\hline & 2. Partly uniparous, partly multiparous & 0 & 0 \\
\hline & 3. Generally multiparous & 16 & 66.7 \\
\hline \multirow{4}{*}{$\begin{array}{l}\text { Intensity of the greenback } \\
\text { (green shoulder) }\end{array}$} & 0. White shoulder & 3 & 12.5 \\
\hline & 3. Slightly & 3 & 12.5 \\
\hline & 5. Intermediate & 7 & 29.2 \\
\hline & 7. Strong & 11 & 45.8 \\
\hline \multirow{9}{*}{ Predominant fruit shape } & 1. Flattened & 3 & 12.5 \\
\hline & 2. Slightly flattened & 2 & 8.3 \\
\hline & 3. Rounded & 6 & 25.0 \\
\hline & 4. High rounded & 3 & 12.5 \\
\hline & 5. Heart shaped & 3 & 12.5 \\
\hline & 6. Cylindrical & 0 & 0 \\
\hline & 7. Pyriform & 1 & 4.2 \\
\hline & 8. Ellipsoid & 0 & 0 \\
\hline & 9. Other & 6 & 25.0 \\
\hline \multirow{6}{*}{$\begin{array}{l}\text { Exterior color of the } \\
\text { mature fruit }\end{array}$} & 1. Green & 1 & 4.2 \\
\hline & 2. Yellow & 4 & 16.7 \\
\hline & 3. Orange & 2 & 8.3 \\
\hline & 4. Pink & 2 & 8.3 \\
\hline & 5. Red & 14 & 58.3 \\
\hline & 6. Other & 1 & 4.2 \\
\hline \multirow{3}{*}{$\begin{array}{l}\text { Intensity of the exterior } \\
\text { color }\end{array}$} & 3. Light & 2 & 8.3 \\
\hline & 5. Intermediate & 20 & 83.4 \\
\hline & 7. Dark & 2 & 8.3 \\
\hline \multirow{5}{*}{ Fruit size } & 1. Very small & 9 & 37.5 \\
\hline & 2. Small & 9 & 37.5 \\
\hline & 3. Intermediate & 4 & 16.7 \\
\hline & 4. Large & 2 & 8.3 \\
\hline & 5. Very large & 0 & 0 \\
\hline \multirow{4}{*}{ Fruit shoulder shape } & 1. Flat & 13 & 54.2 \\
\hline & 3. Slightly depressed & 2 & 8.3 \\
\hline & 5. Moderately depressed & 4 & 16.7 \\
\hline & 7. Strongly depressed & 5 & 20.8 \\
\hline \multirow{3}{*}{$\begin{array}{l}\text { Fruit cross-sectional } \\
\text { shape }\end{array}$} & 1. Round & 14 & 58.3 \\
\hline & 2. Angular & 4 & 16.7 \\
\hline & 3. Irregular & 6 & 25.0 \\
\hline \multirow{4}{*}{ Shape of the pistil scar } & 1. Dot & 14 & 58.3 \\
\hline & 2. Stellate & 1 & 4.2 \\
\hline & 3. Linear & 4 & 16.7 \\
\hline & 4. Irregular & 5 & 20.8 \\
\hline \multirow{3}{*}{ Fruit blossom end shape } & 1. Intended & 8 & 33.4 \\
\hline & 2. Flat & 14 & 58.3 \\
\hline & 3. Pointed & 2 & 8.3 \\
\hline
\end{tabular}




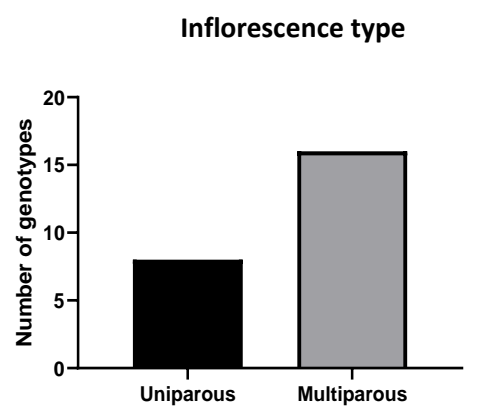

(a)

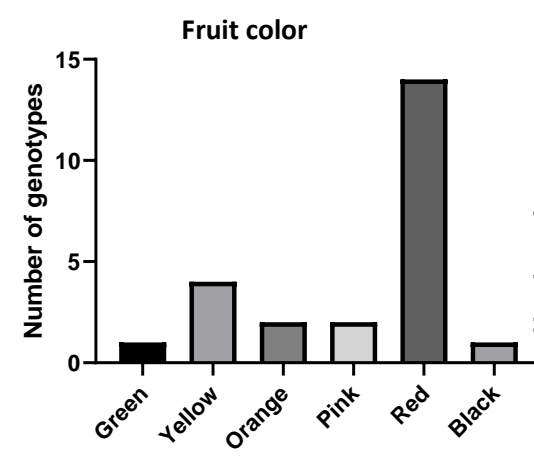

(d)

Fruit cross-sectional shape

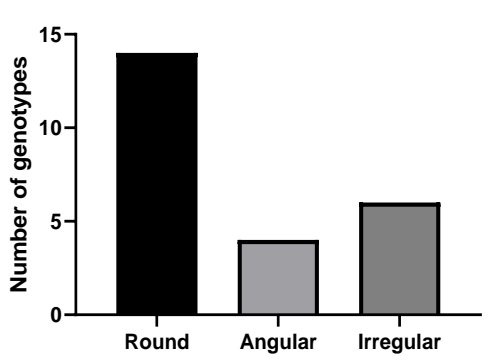

(g)

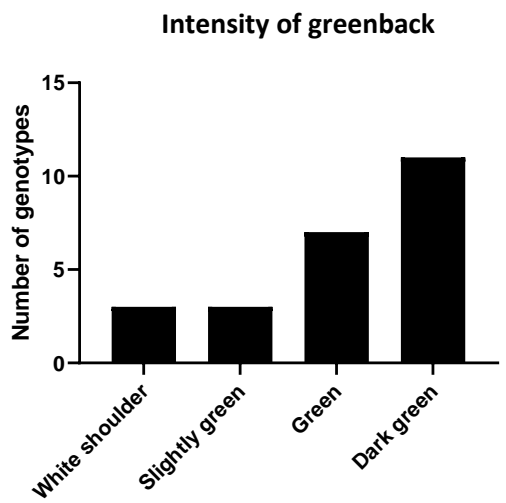

(b)

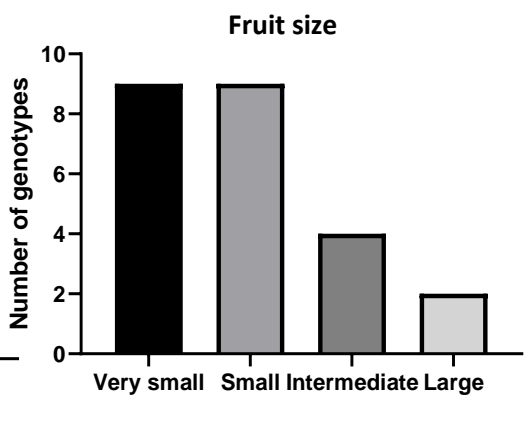

(e)

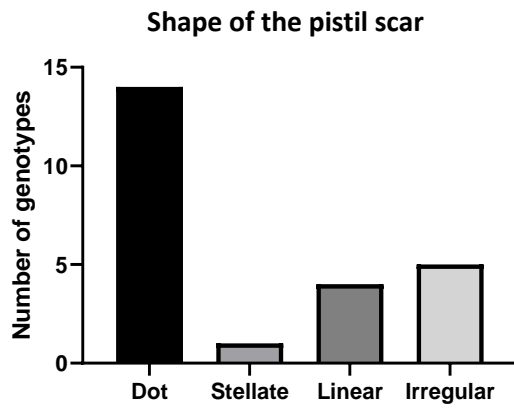

(h)

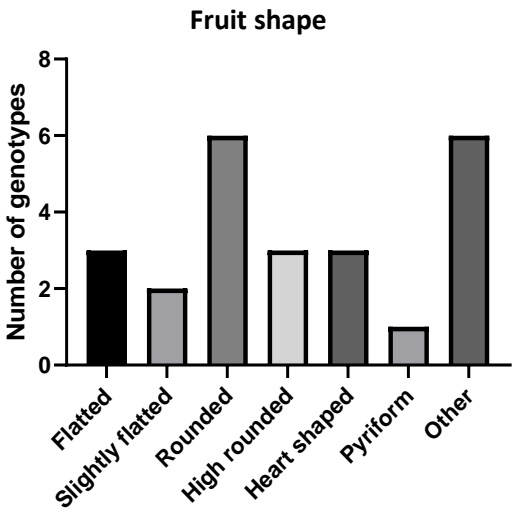

(c)

Fruit shoulder shape

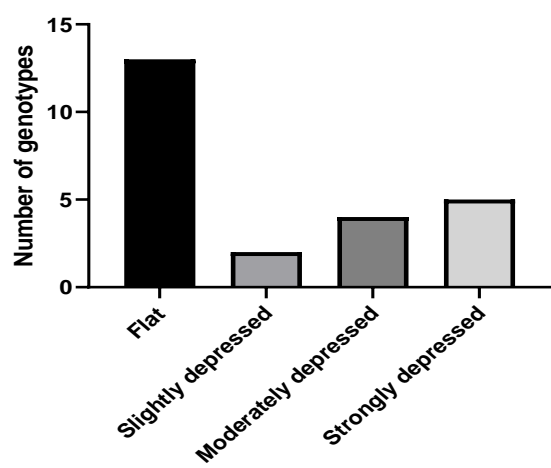

(f)

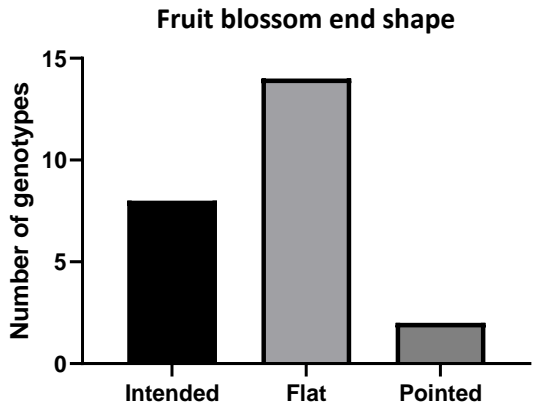

(i)

Figure 1. Classification of the 24 tomato genotypes based on nine fruit-related traits

potential genotypes were identified for breeding ornamental tomato varieties (Figure 2). AU66 and AU67 had un-uniform ripe fruit color, with AU66 having red skin with orange stripes along the fruit as its name Tigerella implies, while AU67 (Greenzebra) had the unique fruit coloration of green skin and some yellow stripes. AU73 (Beams Yellow Pear) had yellow fruit with a shape that looked like a water drop, and AU79 (Reisetomate) had 6-11 separate small fruits on one pistil in the first three inflorescences (the data is not shown). 


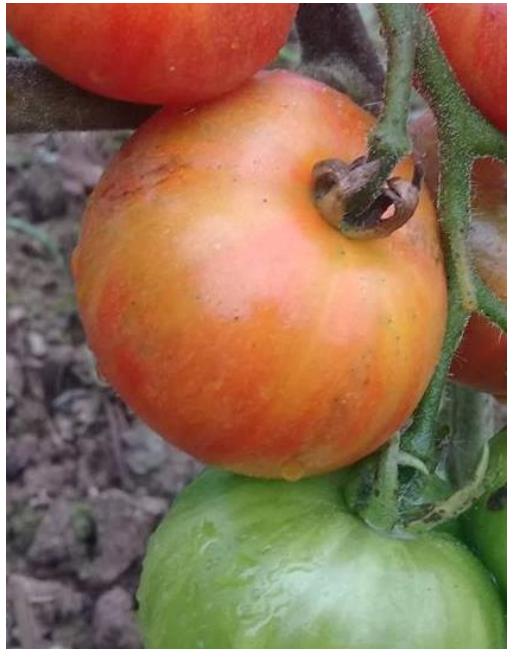

AU66 (Tigerella)

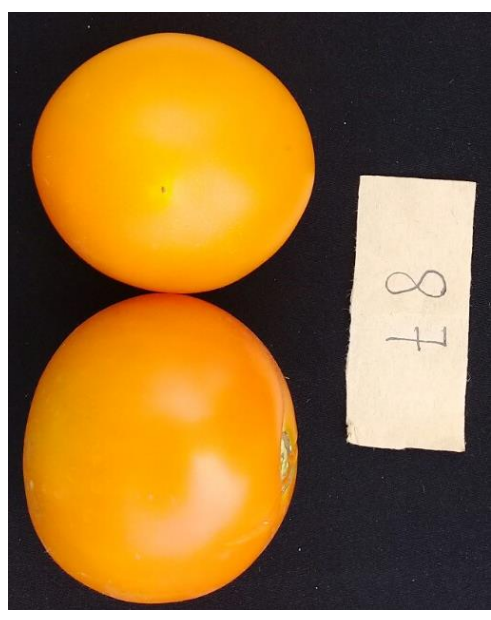

AU87

(Jaune Flamme)

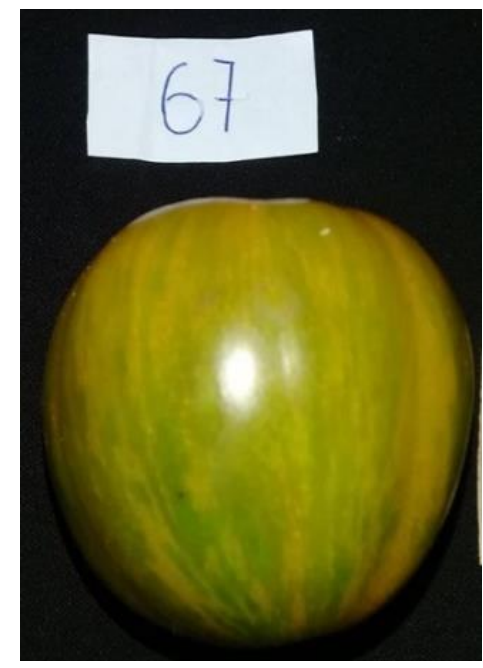

AU67

(Greenzebra)

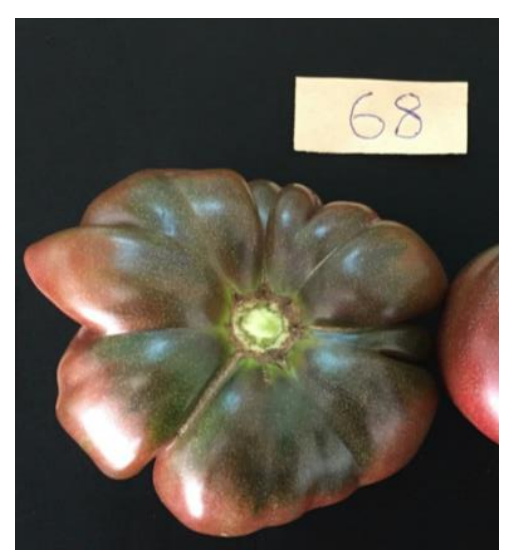

AU68

(Black Karim)

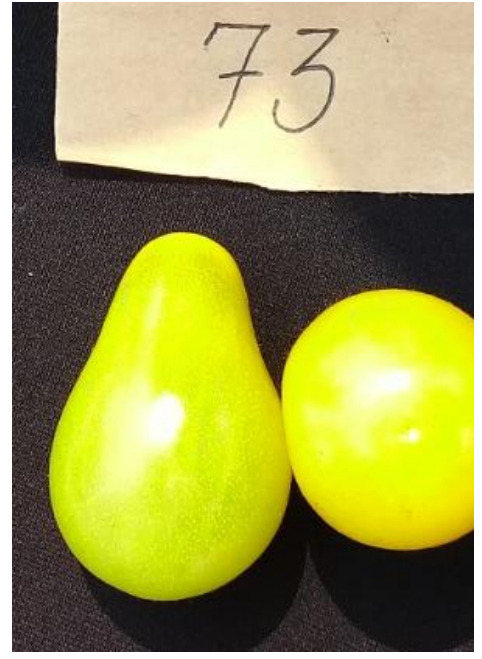

AU73

(Beams Yellow Pear)

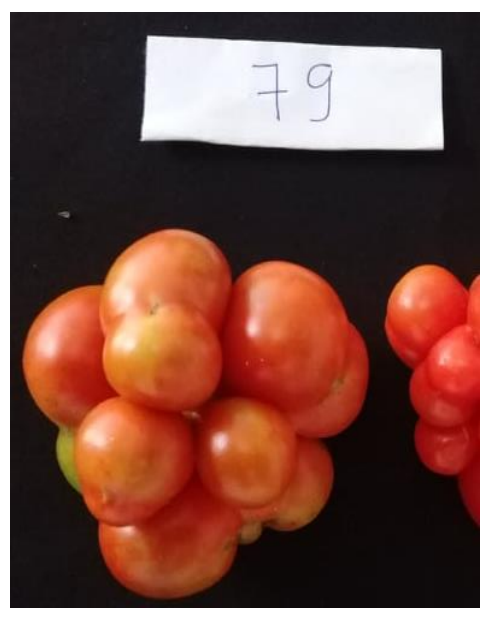

AU79

(Reisetomate)

Figure 2. Unique fruit morphologies of six tomato genotypes

Differences among the 24 experimental genotypes were also observed in other fruitrelated traits. For fruit size, 9 genotypes (37.5\%) were identified in each of the very small fruit and small fruit categories, 4 produced medium fruit $(16.7 \%)$ and 2 produced large fruit $(8.3 \%)$ (Table 3 and Figure 1e). In addition, there were 4 categories for fruit shoulder shape (from flat to strongly depressed; Table 3 and Figure 1f), 3 groups for fruit cross-sectional shape (with the round shape accounting for 58\%; Table 3 and Figure 1g), 4 categories for the shape of the pistil scar (Table 3 and Figure 1h), and 3 categories for fruit blossom end shape (Table $\mathbf{3}$ and Figure 1i). In general, almost all the categories of fruit- related traits identified by IPGRI (1996) were observed in the 24 experimental genotypes.

The observations on fruit morphology of the 24 genotypes had several distinguishable and interesting phenotypes, such as un-uniform color (AU66 with red with orange stripes and AU67 with green with yellow stripes), yellow-water drop shape (AU73), round orange (AU83), and black color (AU68). These fruit colors and shapes will be considered for the further steps of ornamental tomato breeding (Figure 2).

\section{Quantitative fruit traits}

A total of six quantitative fruit traits were evaluated and compared. The results illustrated 
significant differences $(\mathrm{P}<0.05)$ among the 24 genotypes in all of the observed traits.

The fruit length and fruit width varied significantly and could be used to classify the experimental genotypes into four groups, from tiny fruits such as AU70 and AU82, to large fruits such as AU74 and AU88 (Table 4). Statistically significant variation was recorded among the 24 tomato genotypes in other traits, including thickness of pericarp (varied from $0.18 \mathrm{~mm}$ to $0.47 \mathrm{~mm}$ ), number of locules (from 2.0 to over 11 locules), number of seeds per fruit (from 5.35 to 416.0 seeds), and total soluble solids (from $3.28 \%$ to $5.36 \%$ ) (Table 4).

\section{Correlation analysis}

Thirteen qualitative traits measured in this study were analyzed for correlations. The results indicated that fruit size had a significant positive correlation with the fruit cross-sectional shape (0.822), number of locules (0.765), and shape of the pistil scar (0.850). Fruit shoulder shape was significantly correlated with the number of locules (0.747) and shape of the pistil scar

Table 4. Evaluation of six quantitative fruit traits. The data are presented as mean values $(n=10)$; different letters within a column represent significant differences (Tukeys's honest significant difference test, $\mathrm{P}<0.05$ ).

\begin{tabular}{|c|c|c|c|c|c|c|}
\hline Genotype & $\begin{array}{l}\text { Fruit length } \\
\qquad(\mathrm{cm})\end{array}$ & $\begin{array}{l}\text { Fruit width } \\
\quad(\mathrm{cm})\end{array}$ & $\begin{array}{l}\text { Thickness of } \\
\text { pericarp }(\mathrm{cm})\end{array}$ & $\begin{array}{l}\text { Number of } \\
\text { locules }\end{array}$ & $\begin{array}{c}\text { Number of seeds } \\
\text { per fruit }\end{array}$ & $\begin{array}{l}\text { Total soluble } \\
\text { solids (\%) }\end{array}$ \\
\hline AU66 & 3.60 d-f & $4.41 c-f$ & $0.40 \mathrm{a}-\mathrm{c}$ & $2.00 \mathrm{e}$ & $77.60 \mathrm{c}-\mathrm{f}$ & $4.53 \mathrm{a}-\mathrm{d}$ \\
\hline AU67 & $3.94 \mathrm{c}-\mathrm{e}$ & $4.47 c-f$ & $0.38 \mathrm{a}-\mathrm{c}$ & $4.95 \mathrm{~cd}$ & $25.50 \mathrm{i}-\mathrm{k}$ & $4.63 \mathrm{a}-\mathrm{d}$ \\
\hline AU68 & $4.48 \mathrm{a}-\mathrm{c}$ & $6.15 b$ & $0.42 \mathrm{a}-\mathrm{c}$ & $8.42 \mathrm{~b}$ & 86.71 b-e & $4.21 \mathrm{a}-\mathrm{d}$ \\
\hline AU70 & $2.07 i$ & $2.00 \mathrm{i}$ & $0.18 \mathrm{f}$ & $2.00 \mathrm{e}$ & $65.80 \mathrm{~d}-\mathrm{h}$ & $5.12 \mathrm{ab}$ \\
\hline AU71 & $3.91 \mathrm{c}-\mathrm{e}$ & 4.77 b-e & $0.40 \mathrm{a}-\mathrm{c}$ & $4.70 \mathrm{~d}$ & 70.60 d-h & $4.44 \mathrm{a}-\mathrm{d}$ \\
\hline AU72 & $4.58 \mathrm{a}-\mathrm{c}$ & $2.87 \mathrm{~g}-\mathrm{i}$ & $0.34 \mathrm{~b}-\mathrm{e}$ & $2.15 \mathrm{e}$ & 34.00 h-k & $4.72 \mathrm{a}-\mathrm{c}$ \\
\hline AU73 & $3.04 \mathrm{f}-\mathrm{h}$ & $2.28 \mathrm{i}$ & 0.23 ef & $2.00 \mathrm{e}$ & $62.90 \mathrm{~d}-\mathrm{h}$ & $4.90 \mathrm{a}-\mathrm{d}$ \\
\hline AU74 & $4.93 \mathrm{a}$ & $8.16 \mathrm{a}$ & $0.44 a b$ & $8.38 \mathrm{~b}$ & $115.38 b$ & $4.13 \mathrm{a}-\mathrm{d}$ \\
\hline AU75 & $3.50 \mathrm{~d}-\mathrm{g}$ & $3.25 \mathrm{e}-\mathrm{i}$ & $0.31 \mathrm{c}-\mathrm{e}$ & $2.10 \mathrm{e}$ & $65.10 \mathrm{~d}-\mathrm{h}$ & $3.75 \mathrm{~cd}$ \\
\hline AU76 & $3.52 \mathrm{~d}-\mathrm{g}$ & 4.79 b-e & $0.30 \mathrm{c}-\mathrm{f}$ & $9.08 \mathrm{~b}$ & $5.33 \mathrm{k}$ & 4.27 a-d \\
\hline AU77 & $3.47 \mathrm{~d}-\mathrm{g}$ & $2.46 \mathrm{i}$ & 0.24 d-f & $2.00 \mathrm{e}$ & $48.30 \mathrm{f}-\mathrm{i}$ & 3.94 b-d \\
\hline AU78 & $3.06 \mathrm{f}-\mathrm{h}$ & $4.09 \mathrm{~d}-\mathrm{h}$ & $0.33 \mathrm{~b}-\mathrm{e}$ & $5.00 \mathrm{~cd}$ & $7.25 \mathrm{jk}$ & $4.80 \mathrm{a}-\mathrm{c}$ \\
\hline AU79 & $3.00 \mathrm{f}-\mathrm{h}$ & $5.80 \mathrm{bc}$ & $0.19 f$ & $2.00 \mathrm{e}$ & $416.00 \mathrm{a}$ & 3.80 b-d \\
\hline AU80 & $4.47 \mathrm{a}-\mathrm{c}$ & $6.02 \mathrm{~b}$ & $0.33 \mathrm{~b}-\mathrm{e}$ & $5.83 \mathrm{~cd}$ & $46.58 \mathrm{f}-\mathrm{i}$ & $4.37 \mathrm{a}-\mathrm{d}$ \\
\hline AU82 & $2.65 \mathrm{hi}$ & $3.00 \mathrm{f}-\mathrm{i}$ & $0.37 \mathrm{a}-\mathrm{d}$ & $2.00 \mathrm{e}$ & $38.90 \mathrm{~g}-\mathrm{k}$ & $3.62 \mathrm{~cd}$ \\
\hline AU83 & 4.04 b-d & $4.97 \mathrm{~b}-\mathrm{d}$ & $0.41 \mathrm{a}-\mathrm{c}$ & $2.00 \mathrm{e}$ & $95.20 \mathrm{~b}-\mathrm{d}$ & $4.62 \mathrm{a}-\mathrm{d}$ \\
\hline AU85 & 3.24 e-h & $2.95 \mathrm{f}-\mathrm{i}$ & $0.36 \mathrm{a}-\mathrm{d}$ & $2.10 \mathrm{e}$ & 52.60 e-i & $3.28 d$ \\
\hline AU86 & $3.92 \mathrm{c}-\mathrm{e}$ & $6.09 \mathrm{~b}$ & $0.39 \mathrm{a}-\mathrm{c}$ & $6.60 \mathrm{c}$ & $74.00 \mathrm{c}-\mathrm{g}$ & 3.78 b-d \\
\hline AU87 & $3.88 \mathrm{c}-\mathrm{e}$ & $4.41 \mathrm{c}-\mathrm{g}$ & $0.47 \mathrm{a}$ & $2.20 \mathrm{e}$ & $109.90 \mathrm{bc}$ & $5.36 \mathrm{a}$ \\
\hline AU88 & $4.77 \mathrm{ab}$ & $8.19 \mathrm{a}$ & $0.41 \mathrm{a}-\mathrm{c}$ & $11.39 \mathrm{a}$ & $116.50 \mathrm{~b}$ & $4.12 \mathrm{a}-\mathrm{d}$ \\
\hline AU89 & $2.65 \mathrm{hi}$ & $2.96 \mathrm{f}-\mathrm{i}$ & $0.34 \mathrm{~b}-\mathrm{e}$ & $2.00 \mathrm{e}$ & $33.90 \mathrm{~h}-\mathrm{k}$ & $4.19 \mathrm{a}-\mathrm{d}$ \\
\hline AU91 & $2.99 \mathrm{f}-\mathrm{h}$ & $3.21 \mathrm{f}-\mathrm{i}$ & $0.38 a-c$ & $2.00 \mathrm{e}$ & 51.70 e-i & $4.19 \mathrm{a}-\mathrm{d}$ \\
\hline AU92 & $2.66 \mathrm{hi}$ & $2.78 \mathrm{hi}$ & $0.31 \mathrm{c}-\mathrm{f}$ & $2.00 \mathrm{e}$ & $43.50 \mathrm{f}-\mathrm{j}$ & 3.96 b-d \\
\hline AU93 & $2.78 \mathrm{~g}-\mathrm{i}$ & $2.97 \mathrm{f}-\mathrm{i}$ & 0.34 b-e & $2.00 \mathrm{e}$ & $39.70 \mathrm{~g}-\mathrm{k}$ & $4.26 \mathrm{a}-\mathrm{d}$ \\
\hline LSD (0.05) & 0.77 & 1.55 & 0.13 & 1.7 & 37.30 & 1.35 \\
\hline CV\% & 5.30 & 8.81 & 8.98 & 10.43 & 12.26 & 7.69 \\
\hline
\end{tabular}




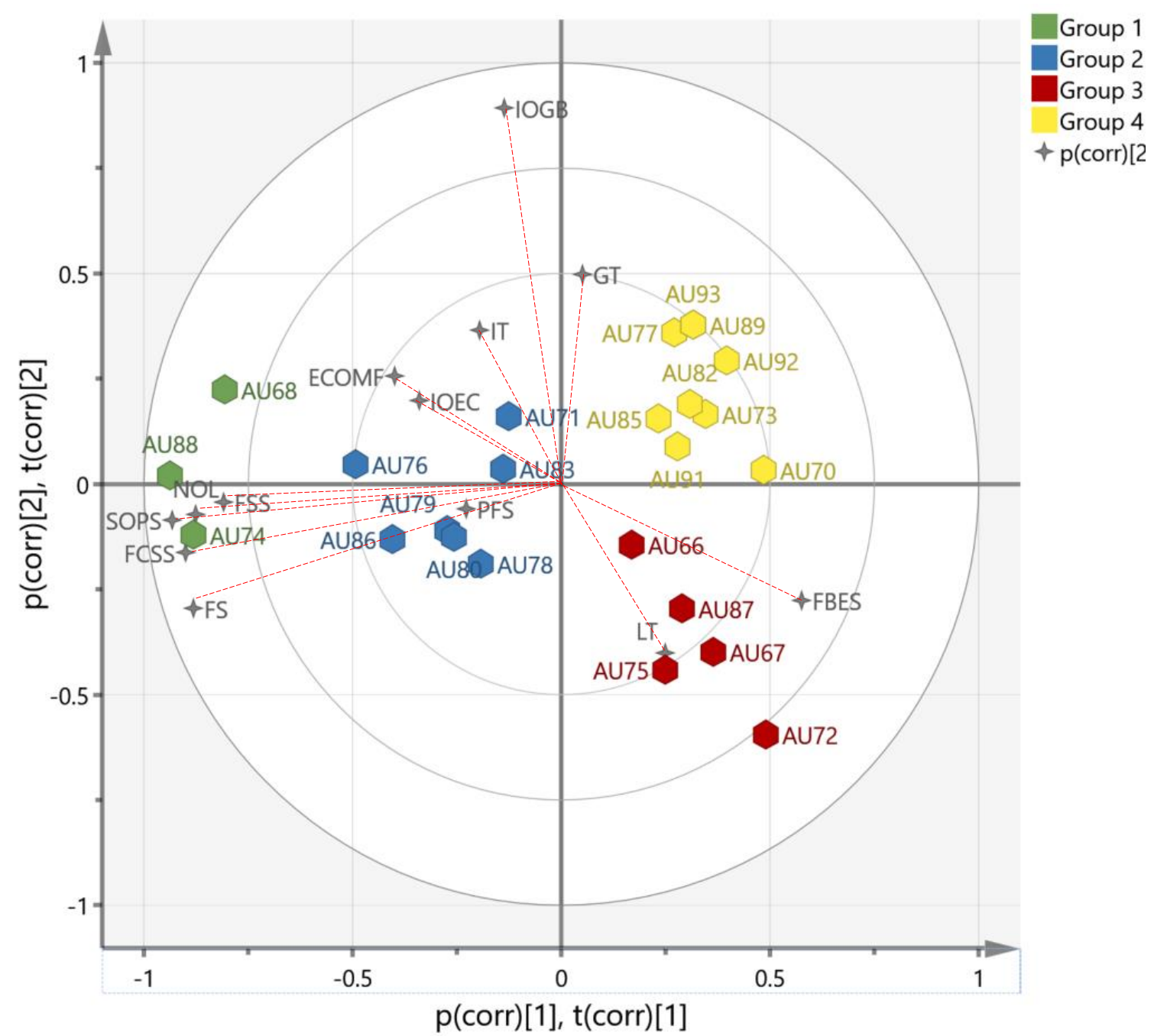

Figure 3. Biplot presents the contribution of the correlation of observed scores (t(corr)) of the 24 genotypes (colored hexagons) and the loading scores ( $p$ (corr)) of 13 traits (grey stars) to the PC1 (horizontal axis) and PC2 (vertical axis). Four groups (represented by four different colors) were classified among the experimental genotypes.

(0.694). Significant positive correlations were also observed between the fruit cross-sectional shape and number of locules (0.752), and the shape of the pistil scar (0.896). Finally, the number of locules was correlated significantly with the shape of the pistil scar (0.793). Other correlations were non-significant (Table 5).

\section{Principle Component Analysis}

The results of the principle component analysis (PCA) of 13 phenotypic traits are presented in Table 6, Table 7, and Figure 3. The results indicated that the variance in $\mathrm{PC} 1, \mathrm{PC} 2$, PC 3 , and PC4 could explain $71.1 \%$ of the total variation. The contributions of these four main principle components were $35.8 \%, 12.7 \%$, $11.9 \%$, and $10.7 \%$, respectively (Table 6).
Based on the loading scores (Table 7) and the positions of the grey stars, which are far away from the PC origin along the horizontal axis (Figure 3), five traits (fruit size, fruit crosssectional shape, shape of the pistil scar, number of locules, and fruit shoulder shape) had a strong influence on PC1. The representative grey star of intensity for the greenback trait is far from the PC origin along the vertical axis, indicating that this trait contributed mostly to PC2 (Figure 3, Table 7). The data shown in Table 7 also illustrate that PC3 included growth type, leaf type, and predominant fruit shape, while the two traits inflorescence type and intensity of exterior color were important in PC4 (Table 7).

In addition, the angles between the vectors (red dashed lines in Figure 3) that connect the 
PC origin to the grey stars indicate the correlations between the characteristics. The smaller the angle is, the more positive the relationship is between two characteristics; in contrast, an angle of nearly $90^{\circ}$ indicates no correlation between two traits. The results showed significant positive correlations among the five main traits of PC1 (the correlation values are described in Table 5) while the main influential trait of $\mathrm{PC} 2$, intensity of the greenback, and three traits related to plant structure, growth type, leaf type, and inflorescence type, had minimal correlation values with the group of five main traits of PC1 (Figure 3, Table 5).

The component pattern based on PC1 and PC2 is exposed in the two-dimensional chart in Figure 3. The chart shows four groups of genotypes, which are represented by four different colors, and the differences among the groups are produced by the corresponding traits. In more detail, group 1 (green) includes AU68, AU74, and AU88. These genotypes can be separated from the others by their fruit size, fruit shape, number of locules, and shape of the pistil scar. Group 2 (blue) includes AU71, AU76, AU78, AU79, AU80, AU86, and AU88. These genotypes tend to be different from the others based on the traits of intensity of the greenback, external color of the mature fruit, and inflorescence type (Figure 3). Group 3 (red) contains AU66, AU67, AU72, AU75, and AU87, and the intensity of the greenback and fruit blossom end shape are the two traits specifying this group (Figure 3). Finally, group 4 includes the remaining 8 genotypes that are similar in growth type and external color of the mature fruit (Figure 3). The details of the typical characteristics of the genotypes in each group are presented in Table 8 with the note that the clusters presented in Figure 4 and Table 8 are not exactly the same as the groups in Figure $\mathbf{3}$ because the groups are classified based on the pattern of PC1 and PC2 only while the clusters in Figure 4 are based on the differences in all the experimental traits among the 24 genotypes.

\section{Cluster analysis of the $\mathbf{2 4}$ tomato genotypes}

The twenty-four tomato genotypes were clustered based on the evaluation of 14 morphological traits. The similarity coefficient among the practical genotypes ranged from 0.25 to 0.93 with the two most similar genotypes being AU77 (OUT-11) and AU93 (OUT-24). At the coefficient of 0.39 , the twenty-four tomato genotypes in this study were classified into six clusters (Figure 4). The frequencies, typical characteristics, and names of the genotypes in each cluster are presented in Table 8. The results showed that fruit size, fruit color, and morphology of the fruit shoulder were the most important characters to distinguish these six groups.

\section{Discussion}

Evaluations of tomato diversity based on morphological traits have been conducted and reported previously in many studies. This study illustrated that three main PCs explained over $60 \%$ of the phenotypic variation and the main traits contributing to the first and second PCs were fruit size, fruit shape, fruit shoulder shape, number of locules, shape of the pistil scar, and intensity of the green shoulder. These results are in accordance with many previous reports: fruit size and fruit shape were important components of the main PCs that have been illustrated in studies on tomato diversity evaluation conducted in the USA and Argentina ( $\mathrm{Hu}$ et al., 2012; Bhattarai et al., 2016). Another fruit-related trait, the number of locules, has also been suggested as a major trait to distinguish tomato genotypes (Glogovac et al., 2012). The presence of a green shoulder was reported as the most important contributor (with five other traits) of PC1 (Tembe et al., 2018). The fruit shoulder shape was one of two main traits contributing to PC1 reported in a study in Nigeria (Ao et al., 2017) However, several other traits that were not fruitrelated or were evaluated as non-significant contributors for the main PCs in this study, such as bio-chemical traits and leaf traits, were reported as the main components to distinguish the experimental genotypes in other studies in Spain and Serbia (Glogovac et al., 2012; Cebolla-Cornejo et al., 2013). Conversely, the results of this present study suggested that the shape of the pistil scar should be considered as 
Table 5. Pearson correlation coefficients between 13 traits of the 24 tomato genotypes

\begin{tabular}{|c|c|c|c|c|c|c|c|c|c|c|c|c|c|}
\hline Pearson's $r$ & $\begin{array}{l}\text { Growth } \\
\text { type }\end{array}$ & $\begin{array}{l}\text { Leaf } \\
\text { type }\end{array}$ & $\begin{array}{l}\text { Inflorescence } \\
\text { type }\end{array}$ & $\begin{array}{l}\text { Intensity } \\
\text { of the } \\
\text { greenback } \\
\text { (green } \\
\text { shoulder) }\end{array}$ & $\begin{array}{c}\text { Pre- } \\
\text { dominant } \\
\text { fruit } \\
\text { shape }\end{array}$ & $\begin{array}{l}\text { Fruit } \\
\text { size }\end{array}$ & $\begin{array}{l}\text { Exterior } \\
\text { color of } \\
\text { the } \\
\text { mature } \\
\text { fruit }\end{array}$ & $\begin{array}{l}\text { Intensity } \\
\text { of the } \\
\text { exterior } \\
\text { color }\end{array}$ & $\begin{array}{c}\text { Fruit } \\
\text { shoulder } \\
\text { shape }\end{array}$ & $\begin{array}{l}\text { Fruit } \\
\text { cross- } \\
\text { sectional } \\
\text { shape }\end{array}$ & $\begin{array}{l}\text { Number } \\
\text { of } \\
\text { locules }\end{array}$ & $\begin{array}{l}\text { Shape } \\
\text { of the } \\
\text { pistil } \\
\text { scar }\end{array}$ & $\begin{array}{l}\text { Fruit } \\
\text { blossom } \\
\text { end } \\
\text { shape }\end{array}$ \\
\hline Growth type & 1.000 & & & & & & & & & & & & \\
\hline Leaf type & 0.159 & 1.000 & & & & & & & & & & & \\
\hline Inflorescence type & 0.000 & -0.324 & 1.000 & & & & & & & & & & \\
\hline Predominant fruit shape & 0.142 & 0.204 & 0.165 & -0.029 & 1.000 & & & & & & & & \\
\hline Fruit size & -0.108 & -0.168 & -0.032 & -0.171 & 0.135 & 1.000 & & & & & & & \\
\hline Exterior color of the mature fruit & -0.084 & -0.211 & 0.150 & 0.180 & 0.089 & 0.233 & 1.000 & & & & & & \\
\hline Intensity of the exterior color & 0.000 & -0.225 & -0.217 & 0.218 & -0.107 & 0.328 & 0.149 & 1.000 & & & & & \\
\hline Fruit shoulder shape & -0.105 & -0.243 & 0.237 & 0.028 & 0.110 & 0.612 & 0.314 & 0.247 & 1.000 & & & & \\
\hline Fruit cross-sectional shape & -0.068 & -0.072 & 0.243 & 0.007 & 0.298 & $0.822^{*}$ & 0.333 & 0.120 & 0.645 & 1.000 & & & \\
\hline Shape of the pistil scar & -0.092 & -0.219 & 0.140 & 0.099 & 0.128 & $0.850^{\star}$ & 0.265 & 0.324 & $0.694^{\star}$ & $0.896^{\star}$ & $0.793^{\star}$ & 1.000 & \\
\hline Fruit blossom end shape & -0.146 & -0.039 & 0.000 & -0.382 & -0.196 & -0.468 & -0.204 & -0.171 & -0.324 & -0.412 & -0.484 & -0.445 & 1.000 \\
\hline
\end{tabular}

Note: ${ }^{*}$ is significant at the $<0.05$ probability level. 
Comprehensive analysis of morphological variation among 24 tomato genotypes oriented to ornamental breeding

\begin{tabular}{cccc}
\hline $\begin{array}{l}\text { Table 6. The contributions of the principle components to variation among the } 24 \text { experimental genotypes based on } 13 \\
\text { qualitative traits }\end{array}$ & Pariance & Cumulative proportion \\
\hline Component & 4.657 & 0.358 & 0.358 \\
\hline 1 & 1.652 & 0.127 & 0.485 \\
3 & 1.546 & 0.119 & 0.604 \\
4 & 1.393 & 0.107 & 0.711 \\
5 & 0.890 & 0.068 & 0.780 \\
6 & 0.713 & 0.055 & 0.835 \\
7 & 0.632 & 0.049 & 0.883 \\
8 & 0.472 & 0.036 & 0.920 \\
9 & 0.423 & 0.033 & 0.952 \\
10 & 0.357 & 0.027 & 0.980 \\
11 & 0.154 & 0.012 & 0.992 \\
12 & 0.063 & 0.005 & 0.996 \\
13 & 0.047 & 0.004 & 1.000 \\
\hline
\end{tabular}

\begin{tabular}{|c|c|c|c|c|}
\hline Traits & PC1 & PC2 & PC3 & PC4 \\
\hline Growth type & 0.051 & 0.497 & 0.598 & 0.125 \\
\hline Leaf type & 0.248 & -0.400 & 0.706 & 0.108 \\
\hline Inflorescence type & -0.195 & 0.365 & -0.174 & -0.778 \\
\hline Intensity of the greenback (green shoulder) & -0.138 & 0.894 & 0.103 & 0.124 \\
\hline Predominant fruit shape & -0.227 & -0.058 & 0.575 & -0.420 \\
\hline Fruit size & -0.881 & -0.295 & -0.011 & 0.154 \\
\hline Exterior color of the mature fruit & -0.399 & 0.256 & -0.214 & -0.151 \\
\hline Intensity of the exterior color & -0.341 & 0.198 & -0.256 & 0.658 \\
\hline Fruit shoulder shape & -0.809 & -0.044 & -0.148 & -0.097 \\
\hline Fruit cross-sectional shape & -0.900 & -0.162 & 0.103 & -0.182 \\
\hline Number of locules & -0.876 & -0.073 & 0.138 & 0.050 \\
\hline Shape of the pistil scar & -0.933 & -0.084 & -0.046 & 0.048 \\
\hline Fruit blossom end shape & 0.575 & -0.277 & -0.393 & -0.205 \\
\hline
\end{tabular}

an important trait for the main PCs (Table 5), which has not been reported in any previous study.

Another aim of this study was to select suitable materials for ornamental tomato breeding. The results show that some genotypes have interesting traits, such as rare color or strange shape, that can be used for ornamental breeding. Previously, many reports have identified the genetic mechanisms of how tomato fruit shape and color are regulated. For example, different fruit colors in tomato are controlled independently or in interaction(s) among a group of genetic elements. Red tomato fruit is the most common color in nature (wild type) as well as in commercialized varieties, while the other colors are created on the background of this red color with different mutation(s). For instance, yellow 


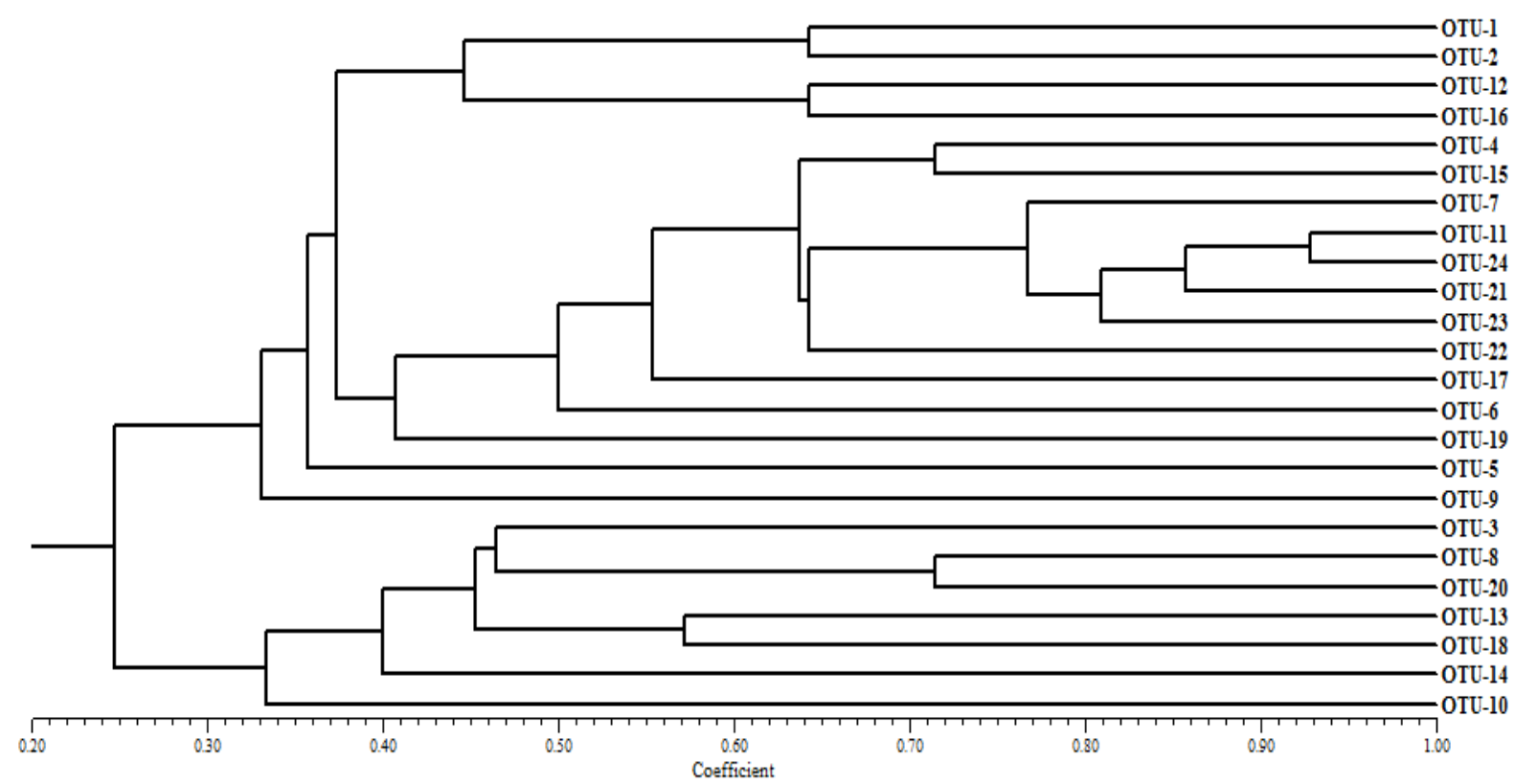

Figure 4. Cluster analysis of the 24 tomato genotypes based on 14 phenotypic traits (The analysis was conducted in NTSYSpc, version $2.10 \mathrm{q}$ using the UPMGA clustering method. The first dashed red line crosses the coefficient value of 0.39 which separates the 24 genotypes into 6 clusters while the second line is to identify the highest similar genotypes: AU77 and AU93 with a coefficient value of 0.93 )

Table 8. Six clusters derived from clustering the 24 tomato genotypes by UPMGA method

\begin{tabular}{cccc}
\hline Cluster & Frequency & Typical characters & Genotype(s) \\
\hline I & 4 & $\begin{array}{c}\text { White/slight green shoulder, small-red fruit, and flat } \\
\text { fruit blossom end }\end{array}$ & AU66, AU67, AU78, AU83 \\
II & 11 & $\begin{array}{c}\text { Indeterminate growth type, very small- red-round } \\
\text { fruit, dotted pistil scar shape }\end{array}$ & AU70, AU72, AU73, AU77, AU82, AU85, AU87, \\
AU89, AU91, AU92, AU93
\end{tabular}

is a recessive mutation on the $\mathrm{R}$ locus while while pink, orange, and green colors are controlled by mutation(s) on the Y locus, B and Del loci, and Gf locus, respectively (Liu et al., 2003). Conversely, black color is not naturally present in cultivated tomato but can be regulated by the genes Aft, atv, and abg from wild species (Jones et al., 2003; Canady et al., 2006; Mes et al., 2008). Similarly, tomato shape expression and control were also investigated comprehensively. Nine main shape categories were identified in tomato fruit (Visa et al., 2014) and four regions on chromosomes $2,3,7$, and 8 carried the main loci related to the regulation of tomato fruit shape (Brewer et al., 2007). Overall, understanding the genetic regulation models of all colors and shapes in tomato enables researchers to use suitable breeding methods to create tomato materials with expected colors and shapes (for different ornamental purposes). In fact, some commercialized tomato cultivars were released for ornamental purposes by combining appropriate decorative traits, such as Sweet Valentine F1 (with a compact plant structure: 30$40 \mathrm{~cm}$ in height, spread $30-35 \mathrm{~cm}$; red heartshaped fruit). The new fruit colors and shapes 
found in this study provide many ideas for ornamental breeding by combining interesting fruit morphologies with different plant structures (such as dwarf stem) and leaf types depending on the demands of customers.

\section{Conclusions}

The present study evaluated significant variation in 19 morphological characteristics including both qualitative and quantitative traits among 24 tomato genotypes. The 24 genotypes were also divided into 6 clusters based on the differences among 13 qualitative characteristics. The results of principle component analysis identified that three main PCs explained over $60 \%$ of the total phenotypic variation. In addition, six fruit traits (fruit size, fruit crosssectional shape, fruit shoulder shape, number of locules, shape of the pistil scar, and intensity of the greenback) were recommended as important components of $\mathrm{PC} 1$ and $\mathrm{PC} 2$ in this study. Finally, six interesting accessions (with strange fruit colors and shapes) were identified as potential materials for further breeding programs of ornamental tomato (AU66, AU67, AU68, AU73, AU79, and AU87).

\section{Acknowledgements}

This work was supported by Vietnam National University of Agriculture under the Grant coded T2018-01-05.

\section{References}

AO C., Aiwansoba R. O., Osawaru M. E. \& Ogwu M. C. (2017). Morphological evaluation of tomato (Solanum lycopersicum Linn.) Cultivars. Makara Journal of Science. 21(2): 97-106.

Bhattarai K., Louws F. J., Williamson J. D. \& Panthee D. R. (2016). Diversity analysis of tomato genotypes based on morphological traits with commercial breeding significance for fresh market production in eastern USA. Australian Journal of Crop Science. 10(8): 1098-1103.

Bhattarai K., Sharma S. \& Panthee D. R. (2018). Diversity among modern tomato genotypes at different levels in fresh-market breeding. International Journal of Agronomy. 2018: 1-15.

Blanca J., Cañizares J., Cordero L., Pascual L., Diez M. J. \& Nuez F. (2012). Variation revealed by SNP genotyping and morphology provides insight into the origin of the tomato. PloS One. 7(10): e48198.

Brewer M. T., Moyseenko J. B., Monforte A. J. \& van der Knaap E. (2007). Morphological variation in tomato: a comprehensive study of quantitative trait loci controlling fruit shape and development. Journal of Experimental Botany. 58(6): 1339-1349.

Canady M. A., Ji Y. \& Chetelat R. T. (2006). Homeologous recombination in Solanum lycopersicoides introgression lines of cultivated tomato. Genetics. 174(4): 1775-1788.

Cebolla-Cornejo J., Roselló S. \& Nuez F. (2013). Phenotypic and genetic diversity of Spanish tomato landraces. Scientia Horticulturae. 162: 150-164.

Danso Y., Akromah R. \& Osei K. (2011). Molecular marker screening of tomato (Solanum lycopersicum L.) Germplasm for root-knot nematodes (Meloidogyne species) resistance. African Journal of Biotechnology. 10(9): 1511-1515.

Glogovac S., Takač A., Tepić A., Šumić Z., GvozdanovićVarga J., Červenski J., Vasić M. \& Popović V. (2012). Principal component analysis of tomato genotypes based on some morphological and biochemical quality indicators. Ratarstvo i Povrtarstvo. 49(3): 296-301.

Greene W. (2012). Vegetable Gardening the Colonial Williamsburg Way: 18th-Century Methods for Today's Organic Gardeners. In., Rodale Books: 240 pages.

Ha T. M. (2015). Agronomic requirements and production methods of tomatoes in the Red River Delta of Vietnam. Journal of Tropical Crop Science. 2(1): 3338 .

Hanson P., Lu S.-F., Wang J.-F., Chen W., Kenyon L., Tan C.-W., Tee K. L., Wang Y.-Y., Hsu Y.-C. \& Schafleitner R. (2016). Conventional and molecular marker-assisted selection and pyramiding of genes for multiple disease resistance in tomato. Scientia Horticulturae. 201: 346-354.

Hauke J. \& Kossowski T. (2011). Comparison of values of Pearson's and Spearman's correlation coefficients on the same sets of data. Quaestiones Geographicae. 30(2): 87-93.

Hoagland L., Navazio J., Zystro J., Kaplan I., Vargas J. G. \& Gibson K. (2015). Key traits and promising germplasm for an organic participatory tomato breeding program in the US midwest. HortScience. 50(9): 1301-1308.

Hu X., Wang H., Chen J. \& Yang W. (2012). Genetic diversity of Argentina tomato varieties revealed by morphological traits, simple sequence repeat, and single nucleotide polymorphism markers. Pakistan Journal of Botany. 44(2): 485-492.

IPGRI (1996). Descriptors for tomato (Lycopersicon spp.). In., Bioversity International: 47 pages.

Jin L., Zhao L., Wang Y., Zhou R., Song L., Xu L., Cui X., Li R., Yu W. \& Zhao T. (2019). Genetic diversity of 
324 cultivated tomato germplasm resources using agronomic traits and InDel markers. Euphytica. 215(4): 69-84.

Jones C., Mes P. \& Myers J. (2003). Characterization and inheritance of the Anthocyanin fruit (Aft) tomato. Journal of Heredity. 94(6): 449-456.

Kaur S., Singh A., Bagati S., Sharma M. \& Sharma S. (2019). Morphological Markers based Assessment of Genetic Diversity in Cultivated Tomato (Solanum Lycopersicon L.) Genotypes. International Journal of Environment, Agriculture and Biotechnology. 3(2): 567-573.

Liu Y. S., Gur A., Ronen G., Causse M., Damidaux R., Buret M., Hirschberg J. \& Zamir D. (2003). There is more to tomato fruit colour than candidate carotenoid genes. Plant Biotechnology Journal. 1(3): 195-207.

Martí E., Gisbert C., Bishop G. J., Dixon M. S. \& GarcíaMartínez J. L. (2006). Genetic and physiological characterization of tomato cv. Micro-Tom. Journal of Experimental Botany. 57(9): 2037-2047.

Mes P. J., Boches P., Myers J. R. \& Durst R. (2008). Characterization of tomatoes expressing anthocyanin in the fruit. Journal of the American Society for Horticultural Science. 133(2): 262-269.

Omondi S. (2017). The most popular vegetable in the world [Online]. Retrieved from https://www.worldatlas.com/articles/the-mostpopular-vegetables-in-the-world.html on July 152020.

Panthee D. R. \& Chen F. (2010). Genomics of fungal disease resistance in tomato. Current Genomics. 11(1): 30-39.

Panthee D. R., Labate J. A. \& Robertson L. D. (2013). Evaluation of tomato accessions for flavour and flavour-contributing components. Plant Genetic Resources. 11(2): 106-113.

Reddy B., Reddy M. P., Begum H. \& Sunil N. (2013). Genetic diversity studies in tomato (Solanum lycopersicum L.). Journal of Agriculture and
Veterinary Science. 4(4): 55-53.

Rohlf F. J. (2000). NTSYS-pc: Numerical taxonomy and multivariate analysis system, version 2.1 Exeter Software. Setauket, New York, USA.

Saito T., Ariizumi T., Okabe Y., Asamizu E., HiwasaTanase K., Fukuda N., Mizoguchi T., Yamazaki Y., Aoki K. \& Ezura H. (2011). TOMATOMA: a novel tomato mutant database distributing Micro-Tom mutant collections. Plant Cell Physiology. 52(2): 283296.

Singh M., Singh A., Kumar A. \& Pandey K. (2018). Molecular diversity of tomato germplasm (Lycopersicum esculentum L.) using lycopene specific markers. Biocatalysis and Agricultural Biotechnology. 16: $340-346$

Srinivasan R. (2010). Safer tomato production techniques: a field guide for soil fertility and pest management. In., AVRDC-The World Vegetable Center: 97 pages.

Tembe K. O., Chemining'wa G., Ambuko J. \& Owino W. (2018). Evaluation of African tomato landraces (Solanum lycopersicum) based on morphological and horticultural traits. Agriculture and Natural Resources. 52(6): 536-542.

Visa S., Cao C., Gardener B. M. \& van der Knaap E. (2014). Modeling of tomato fruits into nine shape categories using elliptic fourier shape modeling and Bayesian classification of contour morphometric data. Euphytica. 200(3): 429-439.

Wang T., Zou Q., Qi S., Wang X., Wu Y., Liu N., Zhang Y., Zhang Z. \& Li H. (2016). Analysis of genetic diversity and population structure in a tomato (Solanum lycopersicum L.) germplasm collection based on single nucleotide polymorphism markers. Genetics and Molecular Research. 15(3): 1-12.

Ziaf K., Amjad M., Shakeel A., Azhar M. \& Saeed A. (2016). Assessment of genetic diversity in tomato for fruit morphology, composition and yield. Pakistan Journal of Botany. 48(6): 2477-2483. 